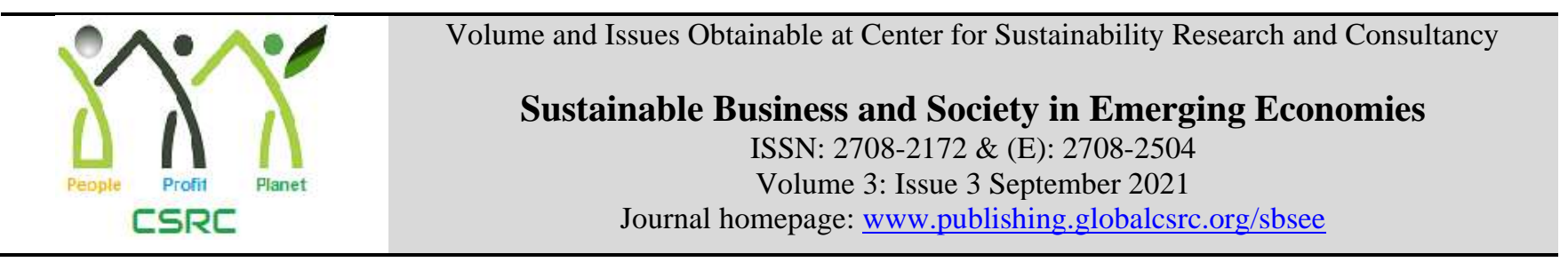

\title{
The Art of Manipulating Masses and Failure of Leadership in Orwells Animal Farm and Pakistani Politics: A Comparative Study
}

*Shahab Rehman, Department of English, Kohat University of Science \& Technology, Hangu

Campus, Pakistan

Shahzad Khan Durrani, Institute of Management Sciences, Kohat University of Science \&

Technology, Hangu Campus, Pakistan

Atteq-ur-Rahman, Department of English, Islamia College University, Peshawar, Pakistan

*Corresponding author's email address: shahab.rehman@kust.edu.pk

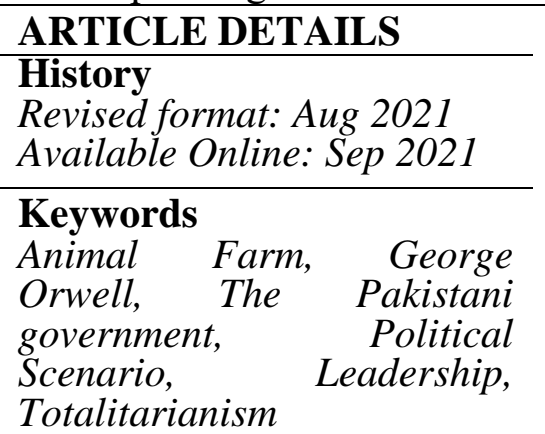

JEL Classification

P16, P26

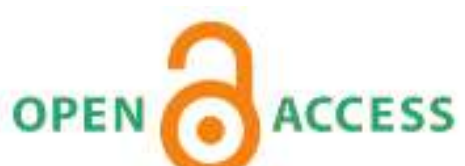

\section{ABSTRACT}

Purpose: The purpose of this research study is to comparatively study George Orwell's Animal Farm (1945) and Pakistani political scenario. The study attempts to find similarities between the two from various aspects such as economy, freedom of speech, leadership, etc., and their effect on the masses.

Design/Methodology/Approach: The study is mainly qualitative as the evidence is gathered from the novella Animal Farm and the public speeches, interviews, and from the social media handles of leading politicians. Critical Discourse Model (CDA), developed by Van Dijk (2001), is employed for the analysis and discussion. The selected texts were then contextualized for comparative analysis.

Findings: The textual evidence collected from the novella Animal Farm and the speeches, interviews, and social media posts from the political leaders reveal that there are certain common elements in both parties. The common elements include censorship on freedom of expression, lack of deliverance on the part of leadership, worsening economy, etc.

Implications/Originality/Value: This research study is significant in the sense it is applicable on various levels such as leadership and its role in shaping the fate of society, the importance of freedom of speech as it paves the way for discussion for a better future of a nation. It also discusses the reason for the failure of economy. Furthermore, it is applicable to prevail justice and equality in society in all forms. This study aimed at discussing the common elements between Animal Farm and Pakistani politics. This is, to the best of my knowledge, perhaps, the first attempt in this regard. It is beneficial for readers in the sense that it provides them to relate the fictional world of Animal Farm to the real happenings in society and its impact on members of the society. Furthermore, it is suggestive in the sense that it provides a solution/alternative for the politicians and stakeholders of the state. 
Masses and Failure of Leadership in Orwells Animal Farm and Pakistani Politics: A Comparative Study. Sustainable Business and Society in Emerging Economies, 3 (3), 389-396.

\section{Introduction}

George Orwell was a British novelist who published Animal Farm in 1945. It mocks the idea of communism in a satirical way. The story is allegorical in nature and it is criticism on communism. Orwell always criticised the philosophy communism. The hope of a promised land and freedom ended in a disaster as the Manor Farm was destroyed by totalitarianism. As stated earlier that Animal Farm an allegory that Baldick (2001) defines as "a story or a visual image with a second distinct meaning that partially hidden behind its literal or visible meaning" (Baldick 2001).

Mr. Jones owns the Manor Farm. He is being the unkindest and tyrant, runs Manor Farm, situated in England. A big pig named Old Major convenes a meeting with all animals living in the farm one night. Keeping in view the limited time he has; Old Major delivers an emotional speech in which he reveals to all the animals that man is evil in his actions. Old Major further adds that all animals are equal and persuade them to come out to revolt against the tyranny of man. He reveals to them an enthusiastic tune called 'Beasts of England'. Old Major gets confused, still two other pigs, Snowball and Napoleon try to help him adjust his thinking into the ways that reflect true spirit of Animalism. After a year or so the animals defeat Mr. Jones and name Manor Farm as Animal Farm.

Animal Farm was a prosperous prospect because the pigs were quite innovative and came up with idea that helped the Farm. Boxer was a hard-worker and it had dedicated his life to the Farm. All the members of the Farm collectively worked for the betterment of the Farm and in the end it helped. Seven Commandments of Animalism were adopted by the members of the Farm and it was agreed that it would be strictly followed. It is evident from the fact that all animals agreed not to act as if they are humans. Using bed for sleeping was prohibited. Using two legs for walking was also banned. It was also agreed not to drink liquor so that they may not end up like a drunk as was the former owner Mr. Jones. All went well as long as Old Major was alive. As soon as he died, everything went south. His two protégé Napoleon and Snowball fiercely fought for rule of Farm. In the end, Napoleon defeats Snowball by means of propaganda. After that, Napoleon snatches the right from other animals cast a vote. Napoleon knows the ways through which the masses can be misled and controlled so he feeds information that benefits his agenda. He forcibly silences those who question his authority and methods. As a result, he becomes dictator and decides the fate of the Manor Farm on his own which ultimately results in a disaster. The idea of Revolution and starry future proved nothing more than just a dream and for Napoleon it was an opportunity to control the Farm for his own benefit to keep himself in power.

The current political conditions in Pakistan are somewhat similar to those of Animal Farm (1945). The ruling party, Pakistan Tehreek i insaf (PTI) won 2018 General Election and officially started ruling on August 17, 2018. The motto and slogan of the ruling party Pakistan Tehreek-e-Insaf (PTI) is 'Tabdeeli' change, and Naya Pakistan. The party leaders have been very critical of the previous government and their policies. They PMLN leaders as corrupt and incapable of running the government. They promised to change it. PTI promised to deliver on their promises but since taking oath as a Prime Minister of Pakistan, Imran Khan, has failed to deliver on its promises and has even acknowledged his lack of preparation. He took many U-Turns on his own statements and claims that taking U-turns have made Prime Minister. In Animal Farm (1945), Napoleon disdained being criticized and same is the case with the current ruling party. The government has been misusing its authority by sending opposition leaders to jail (PMLN leaders such as Shehbaz Sharif, Maryam Nawaz Sharif, Ahad Cheema, Rana Sanaullah etc) and the media is facing censorship. The economy is sinking (Malik, 2019) as it did in Animal Farm when Napoleon insisted on building Windmill and it did not provide favorable conditions. As a result the ruling party blames everything on the previous government and that all politicians are corrupt as did Napoleon when he and his follower blamed Snowball for everything. This narrative sells and is popular among masses. PTI's 2014 Dharna had too many side effects on Pakistan's economy (Mulla, 2017). Both Napoleon and Imran Khan promised 'Revolution' and 'Tabdeeli and Naya Pakistan' respectively but it has not worked so far 
as the country faced wheat crisis, sugar crises, more loans from IMF (Malik, 2019).

\section{Research Questions}

Q1. In what ways the elite class manipulate the masses both in Animal Farm (1945) and the political leaders?

Q2. How is Pakistani political scenario similar to that of Animal Farm (1945)?

\section{Limitation of the Study}

A text can be investigated from different aspects but this study limits itself to examine and analyse Animal Farm for the exploitation of power, elitism and false. Similarly, there are numerous issues for the current ruling party in Pakistan can be criticized but this study concerns itself with the state of economy, freedom of speech and censorship, false promises given by the leaders to the people.

\section{Significance of the Study}

This study concerns itself with comparative study of George Orwell's Animal Farm (1945) and current Pakistani Government. This research study is significant in the sense that it highlights and discusses the common elements both parties i.e. Animal Farm and current Pakistani political scenario. It is significant because it brings forward the problems for the common people to note and understand so that they may take their decision wisely regarding their representatives. Furthermore, it signifies the importance of free speech as it creates a dialogue and accountability of the government officials with the aim to improve the lives and state of the nation.

\section{Literature Review}

Van Dijk (1998) opines that that "Critical Discourse Analysis is a type of discourse analytical research that primarily studies the way social power abuse, dominance and inequality are enacted, reproduced and resisted by text and talk in the social and political context. With such dissident research, critical discourse analysts take explicit position, and thus want to understand, expose and ultimately to resist social inequality." The primary aim of Critical Discourse Analysis is to critically examine and interpret discourses as well as understand the discourses so that these discourses can either be resisted on accepted. According to Faud (2016), the major characters and their approach in The Animal Farm nothing short that a totalitarianism. The major characters, such Old Major and Napoleon find new ways to manipulate and exploit the common folks in order to fulfil their own goals. They employ certain strategies to convince and manipulate people such propaganda campaigns, and sometimes the use of force to silence people as in the case of Napoleon. Yasin (...) in this regard states that propaganda campaign supported and advance by the media in Animal Farm registers the fact that the elite employ media to run their PR so that they can convince people. They not only use for their own PR but also to silence the opposition and any kind of criticism which is what happened in Animal Farm where Napoleon used brute force to silence his critics. Majority of the common folks were misled by their propaganda campaign and they readily believed it and those who did not believe, were forcefully influenced and bullied.

For Abubakar quotes Interior Minister regarding their strategy to control dissent. They strategy is to imprison every individual whom they consider 'thief' and 'corrupt' and in this way every critic of the government will be silenced and put behind the bars. For Abubakar, this strategy is dangerous as it entails grave consequences for democracy to thrive in the country.

Osama in his essay, published in Herald, states that throughout his political career, Imran Khan preached idealism, perfect future, prosperity and fighting the corrupt elements. Once, he became Prime Minister, most of his cabinet members are those who left other political parties and joined PTI just for the sake of power and these members have failed him miserably. He did not fulfil the hope which he had given to the people. Similarly, the followers of the PTI are too blind and they readily believe whatever is told to them and they defend anything the party leaders claim. The followers often criticize and abuses the critics of the party' approach. The author raises questions on the leadership of Imran Khan as he is unable to handle 
the country on many fronts.

Post (2009) in his detailed analysis, discussed the speeches of the presidential candidates during 2008 US Elections. The authors applied CDA in order to analyse speeches of Barak Obama, and John McCain. The author concluded that both the politicians' statements during the election campaign and their actions are contradictory. They employ certain linguistics terms and tools to persuade people and convince them so they can get higher number of votes. The kind of vocabulary that they employ is quite well-picked. The author concludes that this approach is extremely fruitful as the voters are persuaded by the charming language and linguistics terms.

In his research article, Fronkwa (2015) investigated and analysed the vital role of national newspapers on the issues that are related to state policies such as budget. The researcher concludes that newspapers' approach completely changes from objectivity to subjectivity when the issues are related to budget. Most of the newspaper report according to their own agenda and this coverage is mostly negative and it agitates common citizens of the state.

\section{Methodology}

Qualitative approach has been used in this research study. The theoretical framework used for this study is Critical Discourse Analysis (CDA) developed by Vvn Dijk \& Norman Fairclough (1993). Wodak \& Meyer (2009) state that CDA is a multidisciplinary in its nature. According to van Dijk (2001) CDA primarily concerns itself with the problems of society and '...especially on the role of discourse in the production' (p. 96). "Discourse" as defined by Oxford Advance Learners Dictionary (OALD) is "a long and serious treatment or discussion of a subject in speech or writing". Discourse is employed to persuade the audience, to attain strong position and to dominate intellectually. According to Rogers (2004) CDA is quite different than other methods of discourse analysis as it is not only descriptive and interpretative but at the same time offers to answer the questions of why and what (p. 3). It can be also said that Discourse can be employed for dissent and for criticism as well. Luke (1997), in this regard, states that "Given the power of its written and spoken word, CDA is necessary for describing, interpreting, analyzing and critiquing social life reflected in text'. Additionally, Fairclough (1993) contends that "CDA strives to explore how these non-transparent relationships are a factor in securing power and hegemony, and it draws attention to power imbalance, social inequities, non-democratic practice, and other injustices in hopes of spurring people to corrective actions."

The researcher employs CDA to analyze, interpret the theme of totalitarianism and false hopes given by the elite in Animal Farm with the current ruling party and its politics in Pakistan. This study is an effort to find similarities between the two; in exercising their power during the governance.

\section{Analysis}

Question: In what ways the elite class manipulate the masses both in Animal Farm (1945) and the political leaders?

Orwell's Animal Farm is satirical in nature as it criticizes communism for its ideals and practices. There are certain characters such as Old Major and Napoleon who represent historical figures of the movement. Old Major, a powerful and a sly pig, proposes a rebellion against the farm owner. His ultimate aim is to have a better and free future where everybody is equal. He says "Man is the only real enemy we have. Remove Man from the scene, and the root cause of hunger and overwork is abolished forever" (Orwell, 1945, p. 28). The idea of better future was exhilarating for the rest of the animals as it gave them hope to be free and equal one day. The animal had never imagined anything like this before even in their dreams. They liked the sound of it and they totally accepted the idea presented before them.

Another debated point was whether to consider rats and rabbit as their allies as Major asks:

..here is a point that must be settled. The wild creatures, such as rats and rabbits - are they our friends or our enemies? Let us put it to the vote. I propose this question to the meeting: Are rats comrades?" The vote was taken at once, and it was agreed by an overwhelming 
majority that rats were comrades (Orwell, 1945, p. 30-31).

Old Major's death left a hole to fill. Snowball and Napoleon were two strong candidates to take his place and run the Animal Farm. Both Snowball and Napoleon wanted the position of power so the race became intense as both of them claimed their right to the position. They used different tactics to take advantage and defeat the other. In order to fully convince masses and to crush Snowball, Napoleon declared that Snowball is responsible for the demolition of the Windmill in Animal Farm. This tactic got Napoleon his desired result and masses believed his propaganda as Napoleon says "Comrades, do you know who is responsible for this? Do you know the enemy who has come in the night and overthrown our windmill? SNOWBALL!" (Orwell, 1945, p. 77). Napoleon was quite sly as he understood the importance of fake news and the impact of propaganda on commoners. After this successful attempt, Napoleon made it his habit to mislead masses. On another occasion, Boxer is hurt and there a van to take him away, Napoleon again lies to the animals. Benjamin warns his fellows that "they are taking him [Boxer] away to the knackers!" (Orwell, 1945, p. 116). Everyone is worried after that and questions about the van but Napoleon's supporter is too smart for them as he makes them guilty to even question Napoleon leadership. Squealer tells them "The van had previously been the property of the knacker, and had been bought by the veterinary surgeon, who had not yet painted the old name out. That was how the mistake had arisen." (Orwell, 1945, p. 118). Napoleon time and again uses Squealer to convince masses and make them believe in his leadership. In the beginning, he tries to scare them that "If the pigs fail, then Jones would come back" (Chapter 3, p. 51). Napoleon was aware of the fact that nobody wished to Mr. Jones back as he was a drunkard and a cruel master. They used their fear to his own advantage to easily convinced everyone. Boxer was a hard worker and he spend his whole time for Handworkers such as Boxer were easily manipulated by the likes of Napoleon and his dodgy supporters. Boxer believed till the last breath that the only hope is to blindly follow Napoleon.

'Napoleon is always right' Boxer (chapter 5, p. 66).

Napoleon had Squealer by his side who was a sly customer as he propagated for Napoleon and manipulated animals easily. He reminded them time and again that Napoleon is their only choice for a leader. He told them after Boxer's death that:

No one believes more firmly than Comrade Napoleon that all animals are equal. He would be only too happy to let you make your decisions for yourselves. But sometimes you might make the wrong decisions, comrades, and then where should we be? Squealer (Orwell, 1945, p. 66).

He knew that the animals were highly impressed with Boxer's dedication to the great cause and he played it to perfection as everyone agreed to work harder and harder under the leadership of Napoleon without questioning him. On the other hand, if we compare the Animal Farm with the Pakistani political scenario, there are numerous examples that can be found that validates the notion that such strategies were applied that convinced, and manipulated masses to gain their trust.

The politicians have many members who gave hope to the masses of a bright and a fair world. The slogan of the current government was 'Tabdeeli' roughly translated as 'Change'. The aim was to build a Pakistan that is corruption free. Esteemed member Umar, A. (personal communication, Jan 31, 2016) stated that "petrol price without taxes is Rs.46.8 and taxes (PDL+GST) on it are Rs.24.5 so the total tax on petrol is now equal to 52\%" when he was part of the Opposition party. Ironically, when Asad Umar became Finance Minister, he failed to successfully implement his suggested plans. In fact, the prices were increased Ironically, he not only increased the petroleum prices but also defended the move. (Kiyani, K, April 2, 2019). Another PTI leader, Murad Saeed, who is quite enthusiastic, is hailed for his remarks against opposition parties. During a speech he promised that as soon as Imran Khan becomes Primer Minister, all debt would be paid the next day to IMF (Network, BOL. 2016 May, 31). This was, of course, a sentimental narrative that led masses to believe that Imran Khan is the only saviour. Imran Khan himself is an admirer of Riyasat e Madina. He promises to make the state Riyasat e Madina - a state that is ideal for everyone. (Dawn, 2018, July 26). His vision and his practices as Prime Minister do not match as his government has so far failer to deliver on numerous occasions e.g., wheat crisis, sugar crisis, inflation rate, currency losing 
its value against US Dollars, dip in GDP growth etc. He vowed to not take loans from IMF, rather he would commit suicide. His government did go to IMF for 6-billion-dollar loan (Mulla, 2019). The politics of sentiment sells and it sells well. The masses truly believed that all other parties have lost their credibility and PTI is their only chance. The slogan Tabdeeli i.e. Change was popular among the masses and it led them to vote for PTI. The result, though, has been a disastrous one like Animal Farm (1945).

Q2. What are elements that are common both in Animal Farm and present political scenario?

After taking oath as a Prime Minister of Pakistan, Imran Khan in his first speech to the nation, made many promises and vowed to deliver (August, 2018). He promised to make Pakistan an exemplary state like Riyasat e Madina, which was based on equality, justice, truth, brotherhood and piousness where rulers lived among the masses and had not special treatment. He vowed to chase corrupt politician and jail them. He told the nation that Governor Houses will be open for public and Governors will not live there and that a university will be established in the Prime Minister House. He lashed against the previous governments for taking loans from IMF and other countries and promised that unlike them, he will not take loans at all cost. He also welcomed positive criticism in order to steer the country in right direction. All things look pretty when it is a idea, but problem arises when an idea is test in reality. This is what happened to 'Tabdeeli' and 'Naya Pakistan'. Most of the promises that Imran Khan made, have not been fulfilled. For example, the government took 6 billion dollars loan in their first year (Malik, 2019). The government jailed opposition members without following proper rule of law. Governors still reside in Governor

\section{Houses and Prime Minister House remain PM House and it is not turned into a university}

The current government has so far failed to deliver on its promises that were made to the people. The party leader, Imran Khan, now Prime Minister of Pakistan, has always been against taking loans from other countries and IMF. In theory, this stance and narrative was a success as people cheered for him as it was promised to them that everything would be fine once their rule starts. In practice, things have been different. After taking the oath, the present government have taken loans from Saudi Arabia, and IMF (Rana, Shahbaz 2019 July 23). Napoleon in Animal Farm, always assured the masses that everything will be perfect and that there a golden era just round the corner for all. In theory, it was fascinating and exhilarating but in practice it was a disaster. When things went south, Napoleon blamed his critics and opponent, Snowball, for the failure just like Pakistan government blames everything on Mian Nawaz Sharif, leader of the opposition party PML-N. Imran Khan time and again states that he will never stop chasing Nawaz Sharif.

Boxer, is the most hard-working individual Animal Farm as he blindly trusts Napoleon, and works for the greater future of the farm. He truly believed in Napoleon's leadership as he says "Napoleon is always right," (p. 66) and his own motto that "I will work harder" (p. 66). When Boxer is injured, a truck comes in and he is carried away in it. The truck had a banner attached to it which and inscribed 'Slaughter Horse' on it. It is noticed by Napoleon the animals may find it doubtful so he tricks them. Napoleon tells other animals the truck which has taken away Boxer was formerly used in a slaughterhouse but now it is part of a hospital and is used as an ambulance. Animals saw and witnessed everything with their own eyes yet they believed Napoleon and his followers (Chapter 9, p. 118). This goes on to show the power of narrative as propagated time and again. Similarly, the popular leader of PTI, Asad Umar, once tweeted that then government of PMLN is robbing people by adding surcharges to the fuel prices. He blamed government for the failure of economy and promised that he would take it in right direction once his party wins the general election. His wish came true and PTI won the election and he became Minister of Finance. His approach and policies were not popular among his own party so the party leadership decided that Asad Umar is not capable enough to run the economy so he was officially relieved off his position as a Finance Minister on April 18, 2019. This came as a surprise because the whole party and their followers had strongly advocated for Asad Umar's wizardry, yet they did not object to his removal as they defended this with the counter argument that Imran Khan knows best and whatever he does, is for the best, the way Boxer always maintained that 'Napoleon is always right' (Chapter 5, p. 66). 
Squealer was the one who chiefly propagated for Napoleon. He used various tactics to convince all that Napoleon is their only savior. Squealer paved the way for Napoleon as he would convince people with his charming words. When the Windmill is destroyed, Napoleon decides to not let anyone vote. He snatches their right to cast vote. This step seemed impossible to defend but Squealer succeeds in not only defending the move, but also justifying it that this move is for their own good (p. 119). Squealer convinced them that Napoleon is always right and that he has done everything for their cause (Orwell, 1945, p. 85). This blinding following of Napoleon is applicable to the current political scenario. The followers of PTI believe that the party leader Imran Khan is always right and whatever he does, is best for the country and people. The other party leaders tend to agree with the sentiment and pave way for him. They praise him and manipulate people's opinions. In this regard, we can say that there are many characters like Napoleon and squealer. Some do the propaganda and others reap its reward and anyone who questions them, is a traitor. As a political leader, Imran Khan has a massive numbers follower. The followers of Imran blindly believe in him. His political aides are also his staunch followers. His party members, Naeem ul Haq, Murad Saeed, Jahangir Tareen, Shehryar Afridi, Ziaullah Bangash, registered their allegiance on the social media app, Twitter Imran Khan's decision. Same is the case with other political parties, PML (N) and PPP, where the party leaders Nawaz Sharif, and Bilawal Bhutto Zardari, are considered perfect political leader who cannot do any wrong.

Napoleon and Squealer used media to their own advantage and as they spread fake news to convince masses. They also censored news and information that did not support their narrative and simple imprisoned such animals. In today's Pakistan, the situation is same as media is under immense pressure. The government is censors those media outlets that speak out against government's policies. The government does not like to dissent as many journalists, who have been vocal against their governance, have lost their jobs. The ruling party's official twitter handle @PTI tweeted names of the journalist who in one or another way are against the ruling party's strategies. These journalists were then viciously targeted by the party's followers (The Current, Dec 3, 2020). These journalists were labeled as 'Ghaddar' 'Indian Agents' etc. This shows that the ruling party does not tolerate criticism in any way.

The economy of Pakistan is not doing great as was the case in Animal Farm (1945). When animals started building Windmill, they were told that it would be great for the farm economically and that it would generate revenue. PTI maintained the same narrative that once take oath, the country would be in safe hands and they would hold corrupters accountable. The government did not improve the economic conditions so they persisted with the successful tactics of blaming the previous governments and their corruption. Masses are fine with opposition leader being jailed as they see this success of the party. The problem is that the government is ignoring the corrupt elements within their own ranks which again is similar to the only commandment in Animal Farm (1945) that "All animals are equal but some animals are more equal than others" (chapter 10, p. 126). Most of the current party leader left their previous parties to become members of PTI and their act to join PTI were hailed. One such political figure Firdous Ashiq Awan was part of Pakistan Peoples Party (PPP) for greater part of her political career, left and became a member of Pakistan Tehreek-e-Insaf (PTI) (Tribune, 2017 May, 30). Asad Umar joined PTI in 2011 (Tribune, 2012, April, 18) Usman Buzdar, Punjab CM, in 2018, Mehmood Khan, Khyber Pakhtunkhwa CM, in 2017 and Shah Mehmood Qureshi, current Foreign Minister of Pakistan, joined PTI in 2011 (Tribune, 2011, November, 11). For most of his political career, Imran Khan severly criticized such politician and always maintained that such politician is the root cause for the failure but now that such politician have boosted his party, they are considered ideal. Like Animal Farm (1945) as long as one agrees with the ruling class, everything is forgiven and forgotten.

\section{Conclusion}

George Orwell in Animal Farm (1945) relentlessly criticized Communism. He used allegory and fable for his criticism. Orwell (1945) criticized those who highjack a movement/idea and use it for their own interest which is what happened in Animal Farm (1945). The same kind of characters can be found in contemporary Pakistani politics as most of the politicians look after their own interest. They manipulate 
and mislead masses and play with their sentiments in order to attain their own agendas and group. The current government is not different in this regard. The way Napoleon took over and his totalitarian regime was the reason that Manor Farm was ruined. The politician and stakeholders of the state need to ensure that they deliver on their promises. In case, they face difficulties, the stakeholders need to be honest with their fellow countrymen. This is particularly not applicable to a single political group but it is generally applicable to all the political parties of the country. It is, the only possible way for a country to become successful in all regards be it economy, political stability, security, regional peace, peaceful coexistence and the standard of life of an individual.

\section{References}

Acar, Y. Corruption of power by media in animal farm. Academia.edu

Uman, K, F. (2016). The portrayal of totalitarianism in george orwell's animal farm. State Islamic Unviersity Kalijaga Yogyakarta.

Fairclough, N. (2003). Analysing discourse. Routledge. New York

Luke, A. (2002). Beyond science and ideology critique: developments in critical discourse analysis. Annual Review of Applied Linguistics P96-110. Cambridge University Press

Orwell, G. (1945). Animal Farm: a fairy story. Gutenberg.net.au

Van Dijk, T.A. (1998). Critical Discourse Analysis. Retreived from:

http://www.hum.uva.nl/teun/cda.htm. (1/25/2000).

Post M, M. (2009). Representations of Meaning Within Textual Personas: An Analysis of 2008 US Presidential Campaign Speeches. University of Birmingham.

Fornkwa, M, J. (2015). A critical discourse analysis of newspaper articles on the 2015 state budget of Cameroon in the national press. Yaounde International Symposium on Academic Writing and Mentorship for Juniour Scientists. University of Yaounde

https://www.dawn.com/news/1473278

Network, BOL. (2016 May, 31). Murad Saeed Speech 16th May 2018 in a ceremony at Islamabad. Retrieved from https://www.youtube.com/watch?v=O60VHhmIzz8

The Express Tribune. (2017 May, 17). PPP's Firdous Ashiq Awan joins PTI. Retrieved from https://tribune.com.pk/story/1422984/ppps-firdous-ashiq-awan-joins-pti/

News, D. (2018 July, 26). Pakistan ko Madina ki rayasat banao ga: Imran Khan. Retrieved from https://www.youtube.com/watch?v=BqJ9bulGj_c

Rana, S. (2019, July 23). Pakistan borrows record \$16b in just one year. The Express Tribune

Siddique, O. (2019, Feb 19). Imran khan: raising expectations and not meeting them. Herald Pakistan.

Kiyani, K. (2019, April 2). Finance minister defends increase in petroleum prices.

Siddique, A. (2019, August 21). Pakistan imprisons opposition to silence dissent. Gandhara.refrl.org

The current. 